\title{
Value Chain Production Association for Pink Pepper Bananas: Research in Yen Lac District, Vinh Phuc Province, Vietnam
}

\author{
Tran Nguyen Ly \\ Department of Science and Technology of Vinh Phuc Province, Vietnam
}

Pham Nguyen My Linh

University of Manitoba, Manitoba, Canada

Pham Thai Long

University of Manitoba, Manitoba, Canada

Nguyen Thi Thu Hương

Academy of Finance, Hanoi, Vietnam

Đo Thi Nang

Academy of Finance, Hanoi, Vietnam

Đo Thi Thuc

Academy of Finance, Hanoi, Vietnam

Received: January 1, 2021 Accepted: January 28, 2021 Published: February 10, 2021

doi:10.5296/ber.v11i1.18138～URL: https://doi.org/10.5296/ber.v11i1.18138

\begin{abstract}
In Vietnam, there are various types of bananas, some of them have become regional specialties of many regions such as: Pink Pepper banana, Western banana, King banana, old
\end{abstract}


banana, etc. Nowadays, Pink Pepper banana is the most popular grown banana with high potential for domestic and international markets. In order to contribute to adding value to agricultural products, linking production along the value chain for Pink Pepper bananas is an urgent issue for policy makers as well as businesses and farmers. This article focuses on analyzing the current status of value chain production linkage for this specific type of bananas in Yen Lac District, Vinh Phuc Province, Vietnam, at the same time, showing results, limitations, causes and recommendations to promote production linkages in the value chain for Vietnamese Pink Pepper banana products in the context of world economic integration.

Keywords: Links, Value chains, Pink pepper bananas, Vietnam

\section{Introduction}

Bananas with persimmon pepper for many years have become a trademark of Red river communes in Yen Lac district, Vinh Phuc province, Vietnam. Through the implementation of a pilot model of high technology application, linking production along the value chain, this agricultural product has gradually become the main crop, contributing to changing the economic face of the area. Due to special climatic and soil conditions in Red River areas, Pink Pepper bananas are grown in Yen Lac with beautiful designs and the quality meets VietGap standards.

Growing Pink Pepper bananas with high economic efficiency helps farmers in Yen Lac district eradicate hunger, reduce poverty and get rich. In addition to consumption in the domestic market, Yen Lac's bananas have been exported through official channels to China and Russia. All exported bananas are included in the Project: Building a model to link production along the value chain from production to product consumption, phase 1 deployed by the Department of Science and performed by Technology of Vinh Phuc Province.

However, due to the limited awareness of a group of farmers, they have not truely complied with the obligations to the business, still have thoughts of self-selling, breaking commitments when market prices are high. Pink Pepper Bananas are grown on fragmented areas, small with outdated farming techniques, so the productivity and quantity of bananas in Yen Lac district are quite low compared to other localities. Besides, the output of the product is also uncertain according to the market price because the contract for product consumption has not been signed.

In this situation, in order to promote the socio-economic development of Vinh Phuc province towards sustainability, it requires an increasing role of forms of cooperation and association to compromise the interests of the participants. Value chain production of pink pepper banana products in Yen Lac District, Vinh Phuc Province, Vietnam is a significant issue. Stemming from the above practice, the authors want to share their views and propose a number of recommendations with scientific and practical basis on this issue.

\section{Literature Review}

Farmers and all farmers' association forms in production and business cooperation are no longer new issues in agricultural and rural development and there have been many reports 
and research papers drawing experiences on this issue. Ellis Frank (1993) defines peasant farm household with the basic properties that mainly living on agriculture, using family labor to produce on their own land, not fully participating in input and output markets. This definition allows small farmers to be distinguished from family farm enterprises in developed countries and farmers producing commercial agricultural products in the context of full market input and output. Peasant farmers in developing countries are often stuck in a vicious cycle of low intensity, low productivity, and not profitable subsistence farming. These factors contribute to high levels of poverty in many rural areas. Linking poor farmers to the market is an option to break this cycle, but it requires overcoming many barriers and market imperfections. Small farmers may face a high risk of lacking the skills, technology and financial services to create a marketable surplus - or to provide quality, quantity and type of goods the buyer requires (Eva-Marie Meemken and Marc F. Bellemare, 2017).

According to PG Chengappa (2018), the concept of a value chain differs in terms of focus or target market, although most chains seek to capture the complex interactions between organizations and individuals that are required to create and bring the product to consumers. It is often a range of activities that link vertically interdependent processes to create value for consumers and establish horizontal links with value chains providing intermediate goods and services. The most popular form of association and many countries interested in investing is agricultural cooperatives. Countries with a lot of experiences in organizing cooperative production for small and very successful farmers such as Japan, Korea, and Taiwan. Cooperative organizations and farmer associations play an important role in the Netherlands. Industry and trade associations, in which the commodity association is the horizontal association of the farm, linking the farm disciplines, while the commodity association is the vertical organization, linking the supply of raw materials to the farm's product consumption. Farmers and employees who have representatives of their organizations in government ensure that, once their community interests are in trouble, they are immediately dealt with by consultation. In addition, farm owners also set up technical, informatics, research and technology transfer organizations to support each other (Dang Kim Son, 2006).

Developed countries will continue to rely heavily on agriculture to ensure employment for the rural poor and food security for a growing population and to respond to the challenges posed by climate change and the global food price spike. According to Naomi J. Halewood and Priya Surya (2012), improving efficiency in the agricultural value chain is central to addressing these challenges. Agricultural productivity growth is also important for poverty reduction. Greater productivity can boost farmers' income, especially for farmers and fishermen who have limited resources to leverage in developing and marketing their products. Creating a more efficient value chain also requires the participation of a wide range of stakeholders, from crop farmers and livestock to provide input to distributors.

According to Duong Hoang Lan Chi (2017), building strong enough regulations and sanctions to ensure the operation of the value chain. Regulations should strengthen the legality of sales and purchase contracts between businesses and producers. Provisions on how to determine prices in a flexible contract according to the agreement of the parties, or according to the market price, the minimum deposit, and the appropriate contract term. In 
addition, there should be strong enough sanctions to solve problems arising in the implementation of the link, handle contract breaches thoroughly in order to minimize damage to partners in the association and for the whole society. In farmers' production, scientists have linked with them, helping to create high yield, good quality, beautiful designs, meeting the needs of society. Farmers' products are exchanged in the market and delivered to consumers through businesses. The fact that entrepreneurs support farmers, link farmers, help farmers to sell products is also an important link to promote agricultural production. The state, the government (including the bank) are the regulators, reconciles and controls of these relationships (Ta Minh Son, 2005).

According to Hoang Thi Viet Khoa (2020), it is necessary to have specific preferential policies and policies for businesses when implementing the association of production and consumption of agricultural products through the form of consumption contracts, forming sample fields. Specifically, support businesses on land when businesses expand their specialized farming scale, train human resources for rural areas to be ready to meet the needs of operating preliminary processing and processing factories. variable; Supporting businesses to speed up medium and long-term loans with preferential interest rates to build areas for preliminary processing, post-harvest preservation, investment in machinery and equipment as well as the application of high technology in production and processing. In Vietnam, the Bank's support for the 2008-2014 Agriculture Competitiveness Project trained more than 93,400 farmers in modern farming techniques, fostered the establishment of farmers' organizations linked to agri-businesses and provided critical public infrastructure (The World Bank, 2018).

\section{Method}

The authors mainly use descriptive statistical methods to analyze the reality, the results and limit the production linkage situation of the value chain for pink pepper banana products Yen Lac District, Vinh Phuc Province, Vietnam in the context of world economic integration. Data are collected and aggregated from actual survey data in Yen Lac District, Vinh Phuc Province Vietnam, Vinh Phuc Statistical Yearbook.

\section{Value Chain Production Linkages for Pink Pepper Banana Products in Yen Lac District, Vinh Phuc Province, Vietnam in the Context of World Economic Integration}

\subsection{An Overview of the Current Status of the Pink Pepper Bananas Growing Industry in Yen Lac District, Vinh Phuc Province, Vietnam}

In Yen Lac district, Vinh Phuc province - a flat land along the Red River has soil conditions suitable for banana trees to grow and develop. In 2006, there were two varieties of banana grown in popularity in the district: indigenous banana and banana. Since 2006, some farming households have planted persimmon pepper banana trees on the fields. The results show that the banana tree with persimmon pepper is both easy to grow, easy to care for and brings high economic efficiency. Since then, the area of Pink Pepper bananas gradually expanded. By 2009, persimmon pepper banana trees were chosen to grow more popularly and gradually replaced the native varieties of banana pepper. In 2017, the People's Committee of Vinh Phuc 
province signed decisions No. 1491 and 1492 / QD-UBND dated May 17, 2017 on the establishment of the Board of Directors of two science and technology application research programs "Building pilot models. point of value chain production, application of high technology to Pink Pepper banana products in Yen Lac district" and "Development of pilot models of value chain production linkage, application of high technology for fruit and vegetable products in Vinh Phuc province" in the period of 2017-2020. In which, Building model 01 in Lien Chau commune with the scale of 50 hectares, as a basis for evaluating and completing the model model to organize sightseeing and learning, thereby replicating the banana growing model in Yen Lac district. and surrounding areas for domestic consumption and export. In 2018, Yen Lac's Pink Pepper bananas were exported to Russia and China for the first time. The bananas were granted a collective trademark certificate by the National Office of Intellectual Property in April 2019. Yen Lac District People's Committee identified persimmon pepper banana as the main crop of Yen Lac district.

Changes in banana acreage planted with persimmon pepper in Yen Lac district are presented in Table 1. In 2010, banana area in Yen Lac district reached 223,6 hectares- accounting for $14.24 \%$ of total banana area in the province. In the following years, the banana area in Yen Lac district tended to decrease. By 2018 and 2019, the banana area will start to increase again to 217,5 hectares - accounting for $11.9 \%$ of the province's banana area. Of the total banana area about $60 \%$ is the area of Pink Pepper bananas. For Yen Lac district, banana area in 2019 accounts for nearly $38 \%$ of the total area of fruit trees. The yield of persimmon pepper banana in Yen Lac district averaged 45-50 tons/hectare. The total production of Pink Pepper bananas reached nearly 5 thousand tons of fresh bananas/year (Vinh Phuc Statistical Yearbook, 2019).

Table 1. Bananas growing areas in Yen Lac District, Vinh Phuc Province, Vietnam year by year

\begin{tabular}{|l|l|l|l|l|l|l|}
\hline & Unit & 2010 & 2016 & 2017 & 2018 & $\begin{array}{l}\text { Preliminary } \\
2019\end{array}$ \\
\hline I. Banana planting areas & & & & & & \\
\hline 1.1 Banana areas in the whole province & ha & $1,570.3$ & $1,838.4$ & $1,802.5$ & $1,805.1$ & $1,827.1$ \\
\hline 1.2 Banana areas in Yen Lac district & ha & 223.6 & 185.6 & 187.3 & 214.9 & 217.5 \\
\hline $\begin{array}{l}\text { 1.3 Ratio of banana areas of Yen Lac district to } \\
\text { total banana area of the province }\end{array}$ & $\%$ & 14.24 & 10.10 & 10.39 & 11.91 & 11.90 \\
\hline II. Harvest banana areas & & & & & & \\
\hline 2.1 Harvested banana areas in the whole province & ha & $1,450.0$ & $1,775.1$ & $1,790.6$ & $1,793.7$ & $1,716.8$ \\
\hline 2.2 Harvest banana areas in Yen Lac district & ha & 211.3 & 183.4 & 186.1 & 213.7 & 170.6 \\
\hline $\begin{array}{l}\text { 2.3 Ratio of harvested banana areas of } \\
\text { Yen Lac district to total banana areas } \\
\text { harvested in the province }\end{array}$ & $\%$ & 14.57 & 10.33 & 10.39 & 11.91 & 9.94 \\
\hline III. Area of fruit trees in Yen Lac district & ha & 385.0 & 481.7 & 533.8 & 560.1 & 574.3 \\
\hline $\begin{array}{l}\text { Ratio of banana areas to the total area of fruit } \\
\text { trees in Yen Lac district }\end{array}$ & $\%$ & 58.08 & 38.53 & 35.09 & 38.37 & 37.87 \\
\hline
\end{tabular}

Source: Vinh Phuc Statistical Yearbook 2019 


\section{Macrothink}

Business and Economic Research

ISSN 2162-4860

2021, Vol. 11, No. 1

4.2 Analysis of Production Linkage Status of Pink Pepper Banana Product Value Chain Yen Lac District, Vinh Phuc Province, Vietnam

\subsubsection{General Diagram of the Value Chain of Pink Pepper Bananas in Yen Lac district}

Through the value chain analysis approach, it shows that the production - consumption of persimmon bananas in Yen Lac district has the characteristics of the value chain of agricultural products with 5 basic stages, namely: (1) Input supply; (2) Production; (3) Collection; (4) Trade; (5) Consumption, shown in Diagram 1.

\section{(1) Production input supply}

The input sector has groups of seed suppliers, agricultural material providers, and productive land lease agents.

- Breeding agent: Pink Pepper banana variety is produced by tissue culture method, done by the plant seed production and supply establishments. Farmers and enterprises buy seeds from these facilities or combine seed purchase and self-propagation.

- Agents supplying agricultural materials are agricultural materials agents, distributed scatteredly in localities. Agents have areas to supply agricultural materials at the village and commune levels.

- Factors that lease land for production (farmers): lease to other households according to the market and farmers lease land to businesses through the research and application of science and technology program "model of high-tech application value chain production linkage for Pink Pepper banana products in Yen Lac district" deployed and implemented by Vinh Phuc Department of Science and Technology.

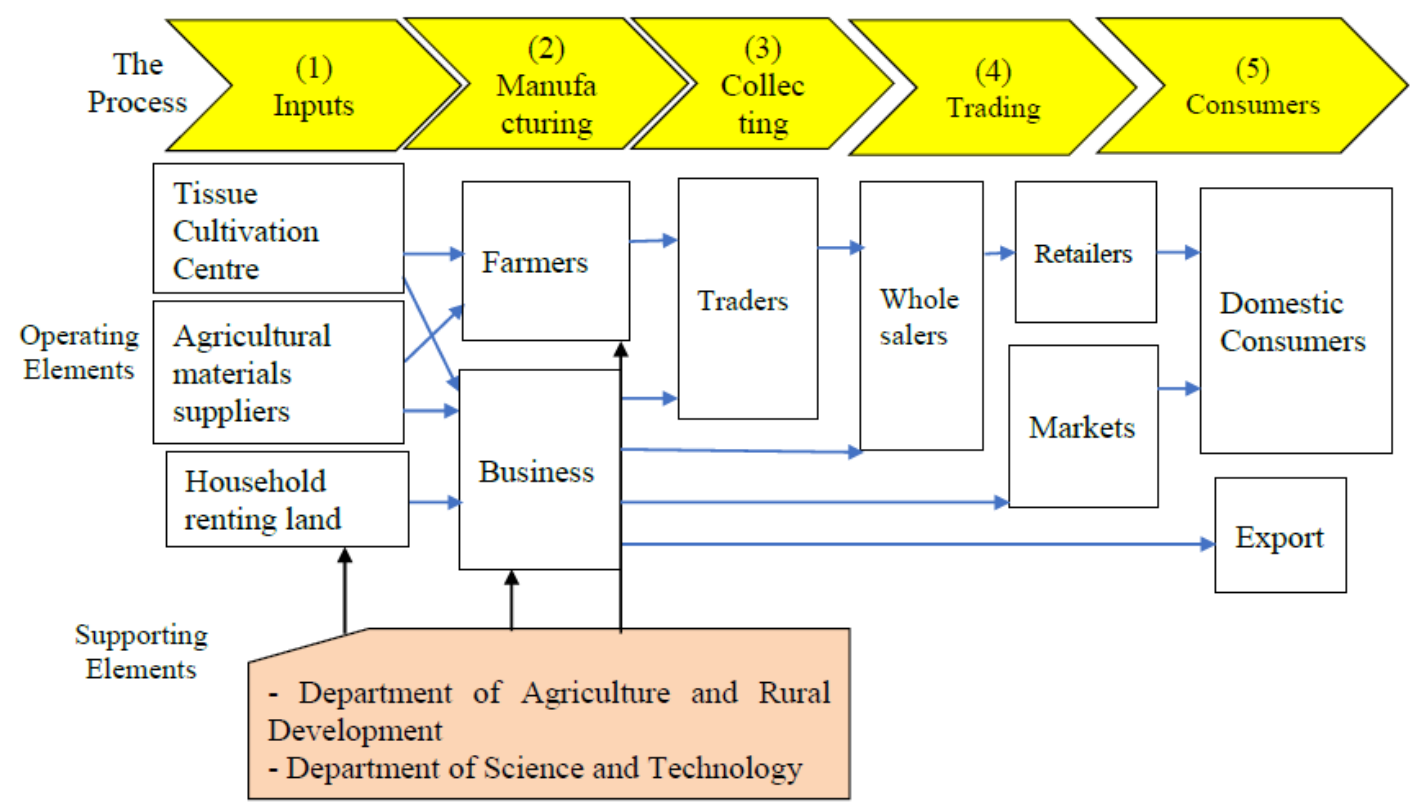

Figure 1. Map of current linkage production of Pink Pepper bananas by value chain Source: Summary of field survey data, 2020 


\section{(2) Production}

Production agents include:

- Farmers growing Pink Pepper bananas in Yen Lac district - Vinh Phuc

- Vietnam Food and Fruit Joint Stock Company - a company that rents land from farmers through the program of research and application of science and technology "Building a pilot model of linking production under the application value chain high technology for Pink Pepper banana products in Yen Lac district "deployed and implemented by the Department of Science and Technology of Vinh Phuc.

\section{(3) Collection}

The agents of the collection stage are local traders. These traders buy Pink Pepper bananas from small farmers, then sell them to wholesalers inside and outside the province.

\section{(4) Commercial}

Trade agents include wholesalers and retailers inside and outside Vinh Phuc province. The wholesalers buy products from traders or businesses, then sell to retailers.

\section{(5) Consumption}

- Domestic consumers: Mainly consumers in the market in Vinh Phuc province and Hanoi market.

- Consumers in export markets: Russia, China, Japan. Currently, exporting activities are carried out by the Vietnamese Food and Fruit Joint Stock Company.

(6) Factors supporting the value chain of Pink Pepper bananas in Yen Lac district include:

Department of Agriculture and Rural Development of Vinh Phuc province: The agricultural extension center under the Department of Agriculture and Rural Development directs the implementation of training on farming techniques according to VietGAP standards for farmers.

Department of Science and Technology of Vinh Phuc province: Supporting through the implementation of the program of research and application of science and technology "Building a model linking production under the value chain of public applications high technology for Pink Pepper bananas in Yen Lac district" with the main contents as follows: Building 01 pilot model. The supports are mainly focused on building business models.

4.2.2 Participation in the Production of Red Pepper Banana in Yen Lac District According to the Value Chain

* The status of linkages of agents participating in the input supply chain for the production chain according to VietGAP.

(1) Bonding status of persimmon pepper banana varieties 


\section{MlMacrothink}

Business and Economic Research ISSN 2162-4860 2021, Vol. 11, No. 1

The survey results show that: The average number of years of rotation of banana garden farming households in Yen Lac district is 2.9 years. Normally, after 2-3 years, the seedlings gradually degenerate and easily get sick, so the farmer households replant the banana garden. During the business cycle of a banana orchard of 3 years, there is a difference in the use of varieties from year to year, namely:

- The first year: $100 \%$ of households choose to buy seeds from propagating establishments by tissue culture method. The main supplier of seeds is the Agricultural Academy, some buy from private seed providers in Hung Yen, which have experience in the cultivation and propagation of persimmon pepper bananas. The relationship of purchase and sale between seed providers and farmers/enterprises is the market relationship without the seed supply contract.

- Year 2 and year 3: 100\% of households choose to self-propagate. After 1 harvest (11-12 months time), at each banana stump, farmers dig out the old stump and keep the strongest sprouts for seeding for the next season. Farmers choose to self-propagate to reduce costs and convenience. However, this approach affects the next banana crop as the variety degenerates and becomes more susceptible to disease.

The results of the farmer household survey (Table 2) also show that, at present, in Yen Lac district, there is no cooperative organization or enterprise to supply seeds and agricultural materials to farmers. Therefore, the source of seeds depends on the production facilities outside the locality, thereby contributing to the increase in seed costs. The fact that farmers self-propagate in years 2 and 3, although it helps to reduce seed costs, increases the cost of care and disease risk, thereby contributing to increased production costs and reduce production efficiency.

Table 2. Proportion of banana growing households choosing the same source of Pink Pepper banana varieties

\begin{tabular}{|l|l|l|l|l|}
\hline No. & Sources of Pink Pepper bananas & Year 1 & Year 2 & Year 3 \\
\hline 1 & The basis of propagation by tissue culture method & 100 & 0 & 0 \\
\hline 2 & Self-propagation & & 100 & 100 \\
\hline
\end{tabular}

Source: Summary of field survey data, 2020

(2) Agricultural material supplier

- The characteristics of the agricultural material supplier

The results of interviews with some agro-material agents/shops in Yen Lac district are presented in Table 3. The average age of the shop owner is 48.5; Dealers/Shops owners have a grade of 12 education, have elementary qualifications (short courses in trading agricultural materials and obtain a Practice Certificate). The average number of years of experience in the agro-material business of the Dealer/Shop owner are 12 years. Agent's business scale is from 1.2 billion to 1.7 billion/year. Stores with lower scale (from 270-300 million/ year). Every year, the Dealers/Shops owners participate in training courses on agricultural materials 
trading techniques from 1 to 2 times, organized by the Vinh Phuc Agricultural Extension Center and by the Material Manufacturing Company agricultural investment.

Table 3. General information of an agricultural material supplier in Lien Chau commune, Yen Lac district, Vinh Phuc province

\begin{tabular}{|l|l|l|l|}
\hline No. & Characteristics & Unit & Quantity/Interpretation \\
\hline 1 & Average age of Agent owner & Age & 48.5 \\
\hline 2 & Educational level & Grade & 12 \\
\hline 3 & Qualification & & Practicing Certificate \\
\hline 4 & Years of experience in the profession & Year & 12 \\
\hline 5 & Holding company & & $\begin{array}{l}\text { Vinh Phuc Plant Protection } \\
\text { Service Company }\end{array}$ \\
\hline 6 & Business capital size & Million dong & 1,200 -1,700 \\
\hline 7 & Scope of supply of agricultural materials & Level & Communes \\
\hline 8 & $\begin{array}{l}\text { Participating in vocational technical } \\
\text { training course of the Dealer/Shop owner }\end{array}$ & Times / year & 2 \\
\hline 9 & Type of supplies provided & & $\begin{array}{l}\text { Fertilizer, Plant protection products, } \\
\text { Plant variety (seed) }\end{array}$ \\
\hline
\end{tabular}

Source: Synthesize field survey data

\section{- Links of agricultural material suppliers with Pink Pepper banana farmers}

The survey results of some agricultural material suppliers in Yen Lac district and compared with the results of the farmer household survey showed that the relationship between agricultural material suppliers and farmers' households. Market relationship without any contract to supply agricultural materials. The diagram of the linkage between agricultural material suppliers and farmer households producing Pink Pepper bananas is shown in Figure 2.

The results of in-depth interviews with some agro-material agents/stores in Yen Lac district also showed that: When making purchases and sales of agricultural products, the shop owner/agent instructs farmers to agricultural materials use, such as which type, dosage rate, and quarantine time required.

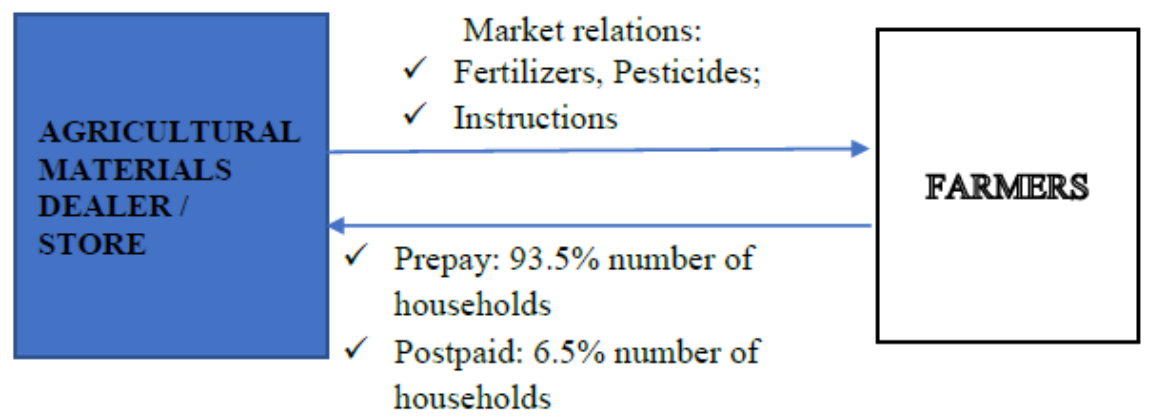

Figure 2. The linkage between agricultural material suppliers and farmer households producing Pink Pepper bananas

Source: Summary of field survey data, 2020 
However, the sale and purchase of agricultural goods is not done under the contract and does not record sales invoices for farmers. This contributes to the difficulty of implementing traceability of agricultural practices of farmers.

Table 4 also shows that: Currently in Yen Lac district, 100\% of banana-growing households buy agricultural products from local shops / agents. There are no cooperatives and enterprises to link with farmers to invest in agricultural materials for farmers.

Table 4. Results of a farmer household survey on the linkage between Agro-Material Supplying Agents/ Stores with Farmers growing Pink Pepper Bananas

\begin{tabular}{|l|l|l|l|l|l|}
\hline \multirow{2}{*}{ No. } & Interview questions & \multicolumn{2}{|l|}{$\begin{array}{l}\text { Number of farmers } \\
\text { answering "yes" }\end{array}$} & \multicolumn{2}{l}{$\begin{array}{l}\text { Number of farmers } \\
\text { answering "no" }\end{array}$} \\
\cline { 3 - 6 } & & $\begin{array}{l}\text { Number of } \\
\text { households }\end{array}$ & $\begin{array}{l}\text { Ratio } \\
(\%)\end{array}$ & $\begin{array}{l}\text { Number of } \\
\text { households }\end{array}$ & Ratio (\%) \\
\hline \multirow{2}{*}{1} & Where do you buy fertilizers and pesticides? & & & & \\
\cline { 3 - 6 } & Agency & 31 & 100 & 0 & 0 \\
\cline { 2 - 6 } & Cooperatives & 0 & 0 & 31 & 100 \\
\hline \multirow{2}{*}{2} & $\begin{array}{l}\text { Has the agent instructed you on how to } \\
\text { use agricultural materials? }\end{array}$ & 27 & 87.09 & 4 & 12.01 \\
\hline \multirow{2}{*}{3} & $\begin{array}{l}\text { When buying agricultural materials from the } \\
\text { dealer/store, do you pay in advance or pay later? }\end{array}$ & & & & \\
\cline { 2 - 6 } & Prepay & 29 & 93.5 & & \\
\cline { 2 - 6 } & Postpaid & 2 & 6.5 & & \\
\hline
\end{tabular}

Source: Summary of field survey data, 2020

Thus, at present, the linkages of the input suppliers for Pink Pepper bananas production are the form of market linkage, but there is no cooperative association model or the Farmer Business linkage model. The practice of producing Pink Pepper bananas according to VietGAP standards of farmers is still limited, lacks the guidance and production orientation according to market signals.

\section{* The status of association of participants involved in production}

People participating in the production of persimmon pepper banana in Yen Lac district now include individual farmers and enterprises (is Vietnam Fruit and Food Joint Stock Company). In which, farmer households produce by means of small, spontaneous, non-linked; the enterprise also implements a "model of production linkage in the value chain, applying high technology for Pink Pepper banana products in Yen Lac district".

\section{(1) Production model of farmer households growing Pink Pepper bananas}

\section{- General information of farmers growing Pink Pepper banana farmers}

The basic information of farmers in Yen Lac district is listed in Table 5. Average age of household head is 56.3 years old, average number of people per household is 4 people, average number of employees/ household 2.8 employees; The average number of years of experience in growing Pink Pepper bananas is 10.8 years, of which the highest is 15 years, the lowest is 7 years. The cultivated area of Pink Pepper bananas on average is $3771 \mathrm{~m} 2$. The 
turnaround years (the time from planting to replanting) is 2.9 years on average, of which 3 years is common with 3 harvests. The survey results also showed that $96.68 \%$ of households use $100 \%$ of their arable land to grow pink pepper bananas.

Table 5. General information of farmer households growing Pink Pepper bananas

\begin{tabular}{|l|l|l|l|l|l|l|l|}
\hline Index & $\begin{array}{l}\text { Age of } \\
\text { household } \\
\text { head }\end{array}$ & $\begin{array}{l}\text { Number of } \\
\text { people in the } \\
\text { household }\end{array}$ & $\begin{array}{l}\text { Number of } \\
\text { employees in } \\
\text { the household }\end{array}$ & $\begin{array}{l}\text { Years of } \\
\text { experience in } \\
\text { banana } \\
\text { cultivation }\end{array}$ & $\begin{array}{l}\text { Banana } \\
\text { planting area }\end{array}$ & $\begin{array}{l}\text { Years to } \\
\text { revolve the } \\
\text { banana } \\
\text { garden }\end{array}$ \\
\hline & Age & People & Labor & Year & M & BB & Year \\
\hline Average & 56.3 & 4 & 2.8 & 10.8 & 3771 & 9 & 2.9 \\
\hline Median & 58 & 4 & 3 & 11 & 2520 & 7 & 3 \\
\hline Max & 71 & 7 & 4 & 15 & 10,000 & 27,78 & 4 \\
\hline Min & 35 & 2 & 2 & 7 & 360 & 1 & 2 \\
\hline
\end{tabular}

Source: Summary of field survey data, 2020

Regarding the planting scale of pink pepper bananas Table 6: In general, the cultivated area of Pink Pepper bananas is less than 5,000 m2, accounting for $74.19 \%$ of the total number of surveyed households. The number of households with area sizes from 5,000 m2 to $10,000 \mathrm{~m} 2$ accounts for $19.35 \%$ of the surveyed households; The number of households with a size larger than 10,000 $\mathrm{m} 2$ accounts for about $6.45 \%$ (Field survey data, 2020).

Table 6. Proportion of households growing Pink Pepper bananas by area size group

\begin{tabular}{|l|c|c|}
\hline Size of cultivated area for pink pepper bananas & Number of households (household) & Ratio (\%) \\
\hline Over $10,000 \mathrm{~m} 2$ & 2 & 6.45 \\
\hline From $5,000 \mathrm{~m} 2$ to $10,000 \mathrm{~m} 2$ & 8 & 19.35 \\
\hline Under 5,000 m2 & 23 & 74.19 \\
\hline
\end{tabular}

Source: Summary of field survey data, 2020

\section{- Farmers' productivity and yield of Pink Pepper bananas}

The survey results of rose banana growing households presented in Table 7 show that: The average yield of pink pepper banana farmers reached 1.59 tons/rod/crop, of which the highest yield was 2 tons $/ 360 \mathrm{~m} 2 / \mathrm{crop}$ and the household with the lowest yield is 1.2 tons/360 m2/crop. In terms of output: an average of 16.9 tons/household/ crop, the household with the highest output is 48.6 tons/crop and the household with the lowest output is 1.6 tons/crop. (Collection of field survey data, 2020). 
Table 7. Farmers' productivity and quantity of persimmon pepper bananas

\begin{tabular}{|l|l|l|}
\hline Targets & Productivity (ton/360 m2/crop) & Quantity (tons / household / crop) \\
\hline Average & 1.590 & 16.9 \\
\hline Median & 1.6 & 10.8 \\
\hline Max & 2.0 & 48.6 \\
\hline Min & 1.2 & 1.6 \\
\hline
\end{tabular}

Source: Summary of field survey data, 2020

- Join the association of farmers growing Pink Pepper banana farmers

(a) Participate in longitudinal linkages between farmers and collectors

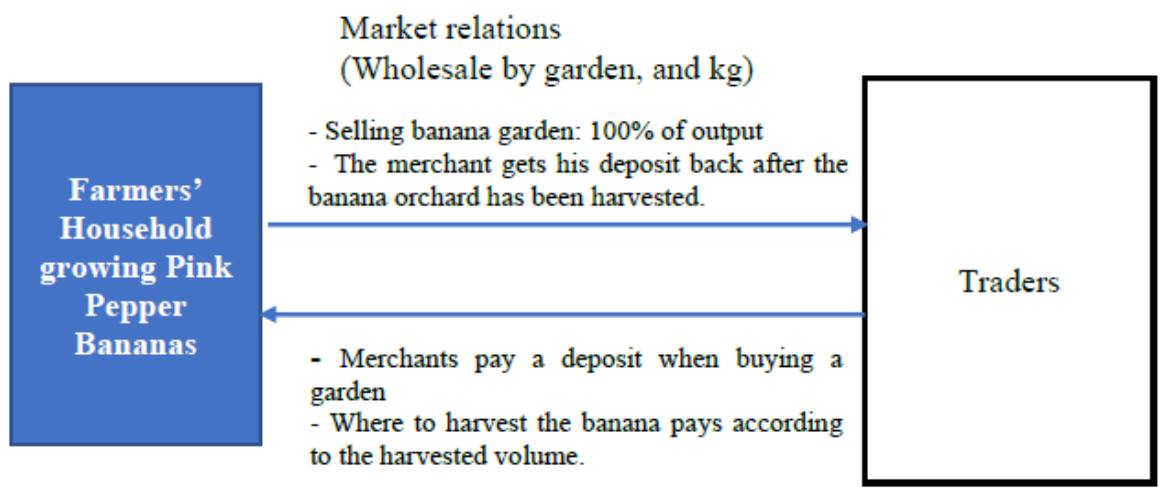

Figure 3. Links between Pink Pepper banana growers and collectors

Source: Summary of field survey data, 2020

The association between farmer households growing Pink Pepper bananas and collectors is shown in Figure 3. It shows the relationship of selling products between households and traders. The form of product trading between households and traders is described as follows: when banana orchards are near the harvesting season, traders and farmers will have a meeting to negotiate on sales and purchases. At the agreement, the trader pays the farmer a deposit to confirm the purchase of the banana orchard. After that time, traders started to harvest bananas depending on their harvesting goals. Specifically, by cutting 6 to 7 years old trees for the purpose of selling bananas when they are green (as food for cooking like a vegetable) and cut 8 to 9 years old for the purpose of selling ripe bananas. Traders will pay farmers by the kilograms they cut per day, they to come there at the purchase price according to the market price of each day. When the banana orchards are harvested, the traders will receive the deposit back from the farmer's household.

In this relationship, traders will face risks such as when the selling price is low, traders can leave their gardens and lose their deposit; Farmers are at risk when facing unfavorable weather such as rain and wind can cause damage to trees, thereby reducing production and revenue. In 2019, there were households with hundreds of millions of dong lost. 


\section{MInstitute ${ }_{\text {Intm }}^{\text {Macrothink }}$}

The results of the farmer household survey showed that the traders were the ones who bought all the bananas from farmers (Table 2.8). At present, there is no enterprise, exporter, cooperative, supermarket or collector in Yen Lac district who buy bananas directly from farmers' households. Moreover, product purchase and sale are mainly done by verbal contracts with $90.32 \%$ of the interviewed households; Some farmer households combine verbal contracts with paper contracts (9.68\% of households), in which the paper contract is only intended to record commitments between the two parties without the witness of the competent authority; No farmer household signs product sales contract with traders on paper contracts in the presence of a competent authority (Field survey data compilation, 2020).

Thus, it can be seen that farmers' consumption of persimmon bananas depends entirely on traders, which shows a non-linked relationship. This makes farmers become weak in bargaining the output prices, as well as lack of support and production guidance from buyers.

Table 8. The proportion of farmer households who sell persimmon pepper bananas to collectors

\begin{tabular}{|c|c|c|c|c|c|c|c|}
\hline No. & $\begin{array}{l}\text { The proportion } \\
\text { of households }\end{array}$ & Traders & Business & Exporter & Cooperatives & Market & Others \\
\hline 1 & Proportion of households (\%) & 100 & 0 & 0 & 0 & 0 & 0 \\
\hline 2 & Production rate $(\%)$ & 100 & 0 & 0 & 0 & 0 & 0 \\
\hline 3 & $\begin{array}{l}\text { Proportion of households } \\
\text { selling products through } \\
\text { verbal contracts }(\%)\end{array}$ & 90.32 & - & - & - & - & - \\
\hline 4 & $\begin{array}{l}\text { Proportion of households } \\
\text { selling products under paper } \\
\text { contracts (\%) }\end{array}$ & 0 & - & - & - & - & - \\
\hline 5 & $\begin{array}{l}\text { Proportion of households } \\
\text { selling products on both } \\
\text { verbal and paper contracts } \\
(\%)\end{array}$ & 9.68 & - & - & - & - & - \\
\hline 6 & $\begin{array}{lcc}\begin{array}{l}\text { Average } \\
\text { (thousand } \mathrm{VND} / \mathrm{kg} \text { ) }\end{array} & \text { price } \\
\end{array}$ & 3.6 & - & - & - & - & - \\
\hline
\end{tabular}

Source: Summary of field survey data, 2020

(b) Participating in cross-linkage and other linkages among household farmers growing Pink Pepper bananas

Results of the survey on the association participation of farmers in Table 9 and the results of in-depth interviews with local officials show that, at present, all banana-growing households produce under a small, non-linked model conclusion. A hundred percent of the households who got the interviews answered that they did not join any cooperative organization, group or cooperate with any business because there is no cooperative group or organization in the area. There are enterprises in the province participating in the industry, but under a closed model, there is no participation of banana farmers with businesses. 
Table 9. Association participating of farmer households to Cooperative/ Group/Enterprise

Unit:\%

\begin{tabular}{|l|l|l|l|}
\hline $\begin{array}{l}\text { Affiliate organization Proportion of } \\
\text { households participating }\end{array}$ & Cooperative / Group & Enterprise & Other links \\
\hline Proportion of households participating & 0 & 0 & 0 \\
\hline Proportion of households not participating & 100 & 100 & 100 \\
\hline
\end{tabular}

Source: Summary of field survey data, 2020

The individual production of small banana pepper farmers in Yen Lac district leads to limitations in good agricultural practices according to VietGAP standards. Results of the farmer households' training on Pink Pepper banana cultivation techniques are presented in Table 10. These results show that: $77.42 \%$ of households have attended a training course on persimmon pepper banana cultivation techniques, organized by the Agricultural Extension Center. However, it only stopped at training (1 time) without monitoring production practices for farmers as well as lack of market orientation for households. Therefore, in the process of cultivating persimmon bananas in recent years, most of the farmers cultivating by experience are self-drawn and spontaneous. Specifically, $100 \%$ of households cultivating according to their own experience learn from them, $64.52 \%$ of households refer to farming experiences from other households; $3.23 \%$ of households learn farming techniques from television and the internet; $9.68 \%$ of the households asked to use fertilizers and pesticides from agricultural material suppliers (Field survey data synthesis, 2020).

Table 10. Places to learn farming techniques of farming households

\begin{tabular}{|l|l|l|l|l|l|l|}
\hline $\begin{array}{c}\text { Places provided } \\
\text { cultivating } \\
\text { techniques }\end{array}$ & $\begin{array}{l}\text { Classes } \\
\text { organized by } \\
\text { the } \\
\text { agricultural } \\
\text { extension } \\
\text { center }\end{array}$ & $\begin{array}{l}\text { Learn } \\
\text { from } \\
\text { other } \\
\text { household } \\
\text { The proportion } \\
\text { of households }\end{array}$ & $\begin{array}{l}\text { Learn } \\
\text { from } \\
\text { tutorials }\end{array}$ & $\begin{array}{l}\text { From } \\
\text { television, } \\
\text { internet }\end{array}$ & $\begin{array}{l}\text { Ask the } \\
\text { store } \\
\text { selling } \\
\text { VTNN }\end{array}$ & $\begin{array}{l}\text { From } \\
\text { experiences }\end{array}$ \\
\hline $\begin{array}{l}\text { Proportion of } \\
\text { households answering } \\
\text { "Yes" }\end{array}$ & 77.42 & 64.52 & 0 & 3.23 & 9.68 & 100 \\
\hline $\begin{array}{l}\text { Proportion of } \\
\text { households answering } \\
\text { "No" }\end{array}$ & 22.58 & 35.48 & 100 & 96.77 & 90.32 & 0 \\
\hline
\end{tabular}

Source: Summary of field survey data, 2020

The individual production of farm households also lead to limitations in access to market information of Pink Pepper bananas growers. Results of the survey on finding out market information of farmers. Table 11 and 12 show that: $87.1 \%$ of the households who got the interviews, have information about product selling prices; $16.13 \%$ of farmers learn about demand for product quality; $12.9 \%$ of households find out about time to purchase products. 


\section{Macrothink}

Business and Economic Research ISSN 2162-4860 2021, Vol. 11, No. 1

There is no household that is looking for information on demand for product quantity and requirements for stamps and labels for products (Field survey data synthesis, 2020).

Table 11. Exploring information on the market of farming household

\begin{tabular}{|l|l|l|l|l|l|l|}
\hline Information type & $\begin{array}{l}\text { Selling } \\
\text { Price } \\
\text { of households }\end{array}$ & Quality & Quantity & Time & $\begin{array}{l}\text { Stamps, } \\
\text { labels }\end{array}$ & Others \\
\hline $\begin{array}{l}\text { 1. Percentage of households } \\
\text { "YES" looking for market } \\
\text { information }\end{array}$ & 87.1 & 16.13 & 0 & 12.9 & 0 & 0 \\
\hline $\begin{array}{l}\text { 2. Percentage of households } \\
\text { "NO" looking for market } \\
\text { information }\end{array}$ & 12.9 & 83.87 & 100 & 87.1 & 100 & 100 \\
\hline
\end{tabular}

Source: Summary of field survey data, 2020

The sources of market information that households learn mainly from other households in the locality with $77.42 \%$ of households; $43.94 \%$ of households get market information from the media; $12.91 \%$ of households ask for information from traders. Information that households learn is mainly information on product selling prices (Field survey data synthesis, 2020).

Table 12. Source of market information researched by farmers

\begin{tabular}{|l|l|l|l|l|}
\hline $\begin{array}{l}\text { The proportion } \\
\text { of households }\end{array}$ & Media & Other households & Associations & Others \\
\hline Percentage of households that did research & 43.94 & 77.42 & 0 & 12.91 \\
\hline Percentage of households that did NOT research & 56.06 & 22.58 & 100 & 87.09 \\
\hline
\end{tabular}

\section{* The status of linkage of participants involved in the collection stage}

Currently, the people participating in the collection of Pink Pepper bananas in Yen Lac district are mainly traders. General information of traders is presented in Table 13. Total trading volume of traders is about 30 tons/year (of which 6 months of selling more is 4 tons/month, and 6 months of selling less is 1 ton/month) .

+ About product purchasing: $90 \%$ of traders 'business is purchased from farmers' households, and $10 \%$ is purchased from other collectors. Farmers 'purchases of products and other collectors' products are verbal agreements, based on mutual trust (Field Survey Data Collection, 2020). 
Table 13. General information of traders

\begin{tabular}{|l|l|l|l|}
\hline No. & Information & Unit & Quantity \\
\hline 1 & Years of experience & Year & 6 \\
\hline 2 & Business output & Tons / year & 30 \\
\hline 2.1 & In which: The proportion of pink pepper bananas & $\%$ & 40 \\
\hline 2.2 & Ratio of bananas & $\%$ & 60 \\
\hline 3 & Buy product & & \\
\hline 3.1 & Proportion of products purchased from farmers' households & $\%$ & 90 \\
\hline 3.2 & Proportion of products purchased by other traders & $\%$ & 10 \\
\hline 4. & Sell products & & \\
\hline 4.1 & Proportion of products sold to wholesalers & $\%$ & 15 \\
\hline 4.2 & Percentage of products sold to schools & $\%$ & 15 \\
\hline 4.3 & Percentage of products sold to supermarkets & $\%$ & 0 \\
\hline 4.4 & The proportion of products sold to retailers & $\%$ & 65 \\
\hline 4.5 & The proportion of products sold to the end consumer & $\%$ & 5 \\
\hline
\end{tabular}

Source: Summary of interview data of traders in Lien Chau-Yen Lac commune, 2020

+ About products sales: Traders have links to sell products with wholesalers, schools, retailers, and consumers in other localities (mainly in Hanoi). In which, the percentage of products sold to wholesalers is $15 \%$, sold to schools is $15 \%$, sold to retailers is $65 \%$, and sold directly to consumers (to order) is about 5\%. The sales relationship between traders and buyers is market relationship, purchase transaction by verbal agreement and based on mutual trust (Field survey data synthesis, 2020).

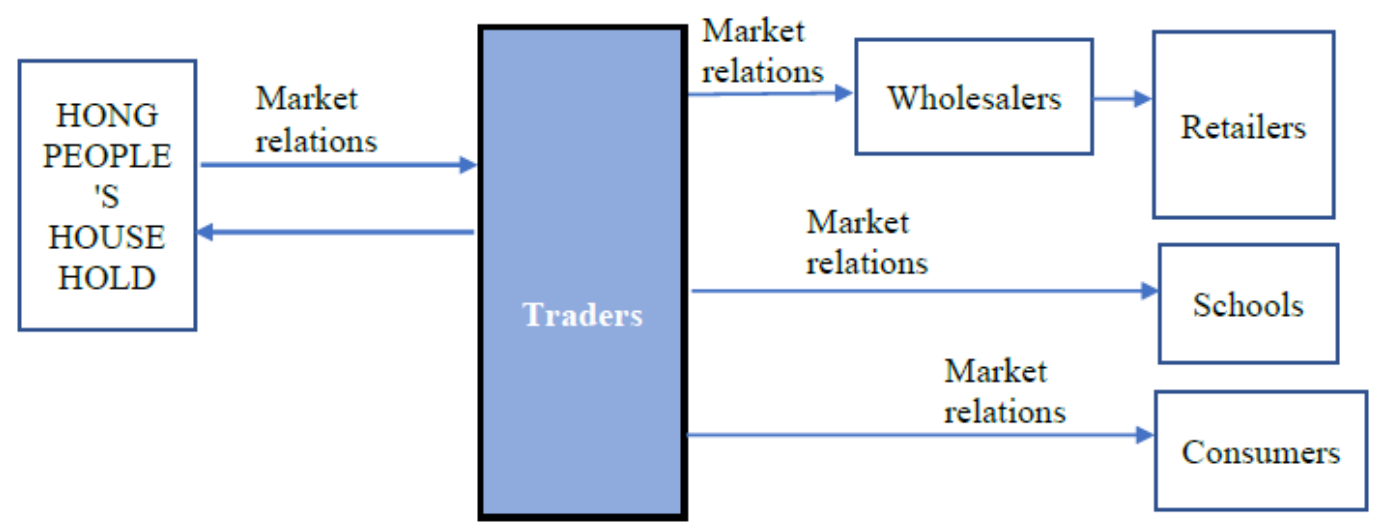

Figure 4. Connection map of a Pink Pepper bananas collector

Source: Collecting information on interviews with traders, 2020

4.3 General Assessment of the Value Chain Production for Pink Pepper Banana Products Yen Lac District, Vinh Phuc Province, Vietnam

\subsubsection{Results Achieved}

- For more than 10 years of bringing the Pink Pepper banana trees to cultivate in Red River area of Yen Lac district, a large area specializing in the cultivation of bananas in the province 
has been established, allowing intensive production and specialization. to apply science and technology in production as well as to apply post-harvest technologies to increase the added value of products. Banana area in Yen Lac district in particular and Vinh Phuc province in general have increased gradually over the years from 2016 to 2019.

- The Pink Pepper banana growing industry of Yen Lac district has been evaluated as the industry with high economic efficiency compared to other vegetables. Since then, the banana tree with persimmon pepper has contributed to improving the efficiency of agricultural production, raising income for farmers, and being considered the enrichment tree of the people.

- After more than 10 years of bringing Pink Pepper banana trees to Yen Lac district, farmers have accumulated a lot of experience in planting and taking care of. Therefore, it contributes to improving production efficiency.

- The implementation of the program of research and application of science and technology "Building a pilot model linking production under the value chain of high technology applications for Pink Pepper banana products in Yen Lac district" has been Achieved a number of remarkable results, such as: The land accumulation of 50 ha from farmers' land lease in 05 years has been smoothly implemented to serve the pilot model construction; There has been the participation of enterprises in the value chain production link model; Applying science and technology such as irrigation technology, post-harvest technology in the pilot model; Organized training courses on cultivation techniques of Pink Pepper banana according to VietGAP standards to farmers; Registered trademark banana Pink Pepper Yen Lac (Summary of field investigation data, 2020).

- Products produced from the pilot model have been linked to high-end markets such as supermarkets and export (Korea, Russia, and China). This affirms that the Pink Pepper banana products in Yen Lac district can meet the strict demands of the market in the context of integration in both quantity and product quality.

\subsubsection{Some Limitations}

- The Pink Pepper banana growing industry has a large production scale, however, both enterprises and farmers have not been able to take initiative in seed sources, thus contributing to high production costs.

- The production scale of Pink Pepper bananas in the region is large; however, the household's consumption depends on traders.

- There are no models to link Pink Pepper bananas production in the value chain such as the model of cooperatives/ Association / Interest groups; Farmer-enterprise production linkage models have not been built.

- Links "four houses" in the bananas industry are limited. There is no close linkage between farmers and businesses; state intervention and support are not consistent; restrict the participation of scientists in production and processing stages. 
Limitations in branding and product promotion.

\subsubsection{The Causes of the Limitations}

- The reason for the limited source of banana varieties: Pink Pepper banana is a plant with seed source produced by tissue culture method, while the province has not built a tissue culture center. The linkage between the seed supplier and the Yen Lac persimmon banana farmer is mainly a type of market linkage (no connection) without seed supply contract.

- Although the area and output of Pink Pepper bananas in the whole region is large, due to lack of linkages in production, each individual household growing Pink Pepper banana has a small scale. Farming techniques are mainly based on the experience of each household. Therefore, the region's banana production does not meet the needs of large buyers (large, uniform quantity, quality criteria meeting food safety standards, traceability of origin). As a result, farmers' consumption of products depends entirely on traders.

- Although the Government has provided support to build business models such as land accumulation and branding, however, it is still limited in investing in science and technology and building synchronous infrastructure for the whole region; has not focused on supporting farmers to build cooperative models and farmer-business linkage models under agricultural contracts or equity contribution.

- Short time for enterprises to lease land; lack of linkage between farmers and companies, so it does not create long-term investment motivation and company stickiness.

\section{Recommendations to Promote the Connection of Particpants Involved in Production by Value Chain for Pink Pepper Banana Products Yen Lac District, Vinh Phuc Province, Vietnam in the Context of International Economic Integration}

5.1 Implementing the "four-house" Linkage Model in the Production and Consumption of Pink Pepper Bananas in the Value Chain

\section{(1) Promoting the role of the Government in managing the "four houses" linkage}

First, the State acts as the organizer of the "four-house" linkages. Vinh Phuc province saw the objective indispensability of association and proposed, guided and promoted self-awareness of each party on the basis of mutual benefits to join in the association, proposed methods of organizing suitable association. suitable and effective. Of course, whether this organizational role can be promoted or not depends on the awareness of all levels of authorities in promoting ownership of the parties to the association on the basis of ensuring benefits. Especially, the farmers are very practical, if they do not bring practical benefits to them but only a plain promise, they are not excited to join the "four-house" association.

Second, the Vinh Phuc province "State" is the guide. "The State" is the person who holds development directions, policies and strategies, has sufficient information on domestic and foreign markets, so it is able to guide and persuade parties to join in, ensuring the linkage. the results "four houses" are sustainable and effective.

Third, "the Government" is the person who supports and creates conditions for the 
"four-house" linkage to operate smoothly. The development of agriculture and the rural economy is a strategic task in the industrialization and modernization of the country, first of all, agricultural and rural industrialization and modernization. However, in the agriculture, there is not a complete and synchronous "four-house" linkage, so the State is forced to participate in the formation, development and complete synchronous linkage. Thus, the role of the "State" in the process of linking "four houses" is the role of "midwife" for the "four houses" to be formed and developed, and also to support production and consumption. Bananas consume persimmons in the value chain.

\section{(2) Promote the business role in the "four-house" linkage}

First, contribute to the farmer's consumption of persimmon bananas. In many areas in Yen Lac District, many farming households have gradually turned to producing goods on an increasingly large scale but cannot sell them, even in the domestic market is also very volatile, making it difficult to market foreign school. Under such conditions, only enterprises with great potential, capturing market demand, can sign contracts with domestic and foreign partners, can sign contracts with farmers for consumption. direct consumption or processing for consumption, creating outputs for farmers. This is also the direct and highest target of Decision 80/2002 of the Prime Minister.

It can be affirmed that, if there is no enterprise to take care of the consumption of persimmon bananas for farmers, the persimmon pepper bananas in Vinh Phuc province cannot reach the market.

Second, "entrepreneurs" contribute to bringing scientific, technical and technological advances into the production and consumption of persimmon bananas, thereby improving the farmer's production level.

Enterprises also have the opportunity to reach the world market, absorb the world's scientific and technological achievements and apply in the country, impart not only the varieties but also the planting technology process. Enterprises also "place orders" with scientists to research and solve problems from production to processing technology and preservation in order to continuously improve production quality and efficiency in the value chain from farm to dining table. The consumption of bananas for consuming persimmons through contracts is only possible, provided that the farmer is the owner of the farm (commonly a family farm), has a large scale of production of commercial agricultural products, is capable of The application of Global GAP and the business must be able to process and consume agricultural products with advanced technology, meet HACCP standards (food hygiene and safety control system).

Third, "the entrepreneur" contributes to change the way of doing business of a farmer who is arbitrarily capitalized to a methodical, basic, contract-bound way of doing business.

The implementation of the "four houses" linkage with the compliance with economic contracts forced farmers to be unable to arbitrarily, especially when signing contracts with enterprises. Business activities in the "four-house" link set the compliance requirements on banana quality, harvesting specifications, delivery time, etc., both to ensure the technological 
process of the business, and to ensure protect benefits for farmers themselves. The enterprises themselves make and implement the commitments in the contract also create the formal business habits for the farmers, and when they are in order, the relationship will be stronger and stronger. On the contrary, if the business arbitrarily, does not comply with the contract, does not respect the interests of the parties in the association, the farmer will break the contract and the "four houses" link will also quickly disintegrate.

\section{(3) Strengthening the capacity of Farmers and Scientists}

To farmers:

- Strengthen training on disease care and disease prevention techniques stemming from the needs of farmers. Training content should come from the "orders" of the farmer;

- Ensuring that the Houses are regularly participating in training courses, transferring technical advances;

- Organize and encourage the formation of groups and groups in the dissemination and exchange of experiences among households in the village and commune. This is an important bridge between scientist and farmer in technology transfer;

- Organize visits to the pilot model that can be applied locally from the support fund of the commune and district extension and the mobilization of contributions from the farmers themselves;

- Propaganda to raise awareness of farmers about product consumption through contracts, building a sustainable link between farmers and input supply enterprises as well as agro-processing and consuming enterprises. ;

- Improve the farmer's access to market information through the local radio information system.

With scientists:

- Completing the document system on intellectual property protection; training and guiding scientists to register for protection of intellectual property rights;

- Investing in technical equipment to meet the research and technical transfer requirements for scientists; and supplement policies to support income, remuneration ... for Scientists when working with the House;

- Training to improve market access capacity for a team of scientists specializing in techniques to transfer technology to the houses.

5.2 Renovating the Contract Method and Strengthening the Effectiveness of the Contract for Agricultural Products to Comply with the Provisions of Law

The contract to purchase raw materials should be renewed by the following method: Enterprises pay in advance of capital and materials (seedlings), provide technology support and directly consume agricultural products; production association in which a farmer is 
entitled to use the value of land use rights to contribute equity capital, to associate, to enter into a joint venture with an enterprise or to leasing land, and then to produce production on the land Contributing shares in joint ventures, associating or leasing and reselling agricultural raw materials to businesses, creating a sustainable bond between farmers and businesses.

Contracts for the consumption of commodity agricultural products between enterprises and farmers must be open contracts and must be signed at the beginning of the crop, the beginning of the year or the beginning of the business cycle in which the purchase price of Pink Pepper bananas to farmers must be is the average floor price at the time of purchase. And, in each contract, there should be a provision specifying the benefit and risk sharing ratio when there is a price difference due to market fluctuations so that the parties are bound by mutual responsibility. When the interests of farmers are closely related, proportional to the benefits of businesses and vice versa, the 4-house model will really bring into play the real effect. To ensure building a sustainable partnership, it is crucial to harmonize the interests of both sides in the business relationship.

\subsection{Strengthening the Role of the Bank in Agricultural Development with High Technology Application}

Characteristics of high-tech agricultural projects are large scale, need a lot of capital, long execution time, long time to recover capital, slow capital turnover, low profits and many risks. . Meanwhile, enterprises themselves also have limited collateral capacity or prove the feasibility and stable income of projects that need to borrow capital. Furthermore, the capital structure of banks with medium and long term capital ratios is often low; At the same time, banks are also bound to the ratio of using short-term deposits for medium and long-term loans and other credit safety principles, so they are not likely to spend medium and long-term loans. Without a special support mechanism to overcome capital difficulties, very few businesses can invest, even if they want to and boldly invest in this area. Therefore, it is necessary to strengthen linkage loans in agricultural production - business with high technology application, with the main link of enterprises and project life loans, and limit component lending, lending in phases.

The credit line of the bank to support agricultural development with high technology application should, first of all, focus on projects and activities of renewing plants and animals; expand the application of new technological achievements in accordance with the process of planting, tending, harvesting, processing, preserving, transporting and consuming, ensuring and improving the quality of pink pepper bananas, meeting the technical standards of the import market; branding and developing supply chains and links, creating a solid output for agricultural products and stabilizing income for farmers.

\subsection{Improving the Quality of Pink Pepper Bananas}

- Human resource training. Training to transfer banana growing technical processes, professional training for managers of cooperatives and cooperative groups in banana production areas. Vocational training for rural workers on planting persimmon pepper banana.

- Propagating and disseminating, guiding advanced production processes and techniques, 
food safety and hygiene, guiding farmers to safely and effectively use seeds, fertilizers and pesticides, and strengthen public supervision. copper in order to reduce the use of fertilizers and pesticides on banana trees, protect the health of consumers and the ecological environment, step by step towards standard production according to customer needs.

- Transferring the technical process of banana pre-processing, preserving and processing bananas after harvest to ensure quality. Processing a variety of banana products such as fresh bananas, dried bananas, dried bananas, banana powder ...

- To invite qualified enterprises inside and outside the province to invest in the construction of raw material zones, to join the production and consumption of bananas along the value chain. Invite enterprises to invest in building Yen Lac Pink Pepper banana preliminary processing factory.

\subsection{Promoting Yen Lac Vinh Phuc Brand and Brand of Pink Pepper Bananas}

- Propagating and introducing on the mass media, newspapers, websites, printing documents, publications, etc. propagating to consumers, customers at home and abroad about the potential and characteristics of banana pepper Hong Yen Lac Vinh Phuc.

- Organize workshops to build high-quality banana production value chains. Invite companies and businesses to participate in the value chain of the banana industry.

\section{Conclusion}

In the context of globalization, the state management agencies of Vietnam, Vinh Phuc province need to complete the legal framework linking stakeholders involved in production in the value chain for agricultural products in general, products. Pink Pepper bananas in particular. On the basis of combining to bring into full play the advantages of geographical location, climate and land, promoting the linkage of actors involved in production in the value chain, Pink Pepper banana products Yen Lac District, Vinh Province Phuc, Vietnam will expand its domestic and international consumption markets.

\section{References}

Bich, P. (2007). Agriculture and rural areas in Vietnam after 20 years of renewal: past and present. Hanoi. National Political Publishing House (Vn.).

Chi, D. (2017). Development of value chains in the fisheries sector of Vietnam. National Institute for Finance. [Online] Available:

https://www.mof.gov.vn/webcenter/portal/vclvcstc/r/m/ncvtd/ncvtd_chitiet;jsessionid=UsGtb8

Communist Party of Vietnam. (2008). Seventh Conference of the Central Committee, Session $\mathrm{X}$ of the Communist Party of Vietnam "On agriculture, farmers and rural areas". Hanoi, National Political Publishing House (Vn.).

Communist Party of Vietnam (2011). Document of the XI National Congress of Delegates. Hanoi, National Political Publishing House (Vn.).

Cuc, N. (2010). Socio-economic issues in rural areas in the process of industrialization and 
modernization. Hanoi, National University Publishing House (Vn.).

Cuc, N. (2009). Vietnam agriculture after 2 years of joining WTO. Journal of figures and events $(V n$.).

Decision No. 3216 / QD-UBND dated November 10, 2015 of the People's Committee of Vinh Phuc province on approving the Scheme on agricultural restructuring associated with the rural labor transition in Vinh Phuc province to 2020 and orientation to 2030. (2015). (Vn.).

Decision No. 07/2016 / QD-UBND dated February 4, 2016 of the People's Committee of Vinh Phuc province on promulgating the regulations on implementing a number of mechanisms and policies to support the restructuring of the agricultural sector in Vinh Phuc province. the 2016 - 2020 period according to Resolution No. 201 / NQ-HDND. (2016). (Vn.).

Decision No. 825 / QD-UBND dated April 10, 2012 of the People's Committee of Vinh Phuc province on approving the planning of science and technology development of Vinh Phuc province to 2020 and vision to 2030. (2012). (Vn.).

Directive No. 11-CT / TU dated 11/11/2016 of the Standing Committee of the Provincial Party Committee on continuing to implement the task of consolidating plots and changing fields in agriculture in the province. (2016). (Vn.).

Duong, P. (2011). Solution to increase the value added in the global value chain of Vietnamese agricultural products. Journal of world economic and political issues. 6(182) (Vn.).

Dung, V. (2011). Discuss the role of agriculture and development policy. Journal of International Studies, 7(398) (Vn.).

Dung, V. (2009). Strengthening the relationship between farmers and entrepreneurs in Vietnam today. Communist Magazine, 800(Vn.).

Ellis, F. (1993). Peasant Economics: Farm Households in Agrarian Development. [Online] Available:https://books.google.com.vn/books/about/Peasant_Economics.html?id=z5u2icAPin gC\&redir_esc=y

Eva-Marie, M., \& Marc, F. B. (2017). Smallholder farmers and contract farming in developing countries. Proceedings of the National Academy of Sciences of the United States of America. https://doi.org/10.1073/pnas.1909501116

Hieu, T. (2002). Linkage between state enterprises and farmer households - A number of theoretical and practical issues. Journal of Agriculture and Rural Development (Vn.).

Hieu, T. (2006). To properly handle the issue of interests in economic linkages between farmers' economies and State enterprises. Journal of Agriculture and Rural Development (Vn.).

Khoa, H. (2020). Developing consumer markets to attract investment in agriculture in Nghe An. Finance Magazine. [Online] Available: 
http://tapchitaichinh.vn/nghien-cuu-trao-doi/phat-trien-thi-truong-tieu-thu-nham-thu-hut-vondau-tu-vao-nong-nghiep-tai- listen-an-317999.html

Minh, H. (2011). Production and export of agricultural products of Vietnam after 4 years of joining WTO, current situation in 2010, prospects for 2011. Journal of Political Theory (Vn.).

Naomi, J. H., \& Priya, S. (2012). Mobilizing the Agricultural Value Chain. Mobilizing the Agricultural Value Chain. [Online] Available:

http://documents1.worldbank.org/curated/en/727791468337814878/071652160_2014072180

41727/additional/722360PUB0EPI00367926B9780821389911.pdf

PG Chengappa. (2018). Development of agriculture value chains as a strategy for enhancing farmers' income. [Online] Available: https://doi.org/10.5958/0974-0279.2018.00001.0

Resolution No. 03-NQ / TU dated December 27, 2006 of Vinh Phuc Provincial Party Committee on the development of agriculture, farmers and rural areas. (2006). (Vn.).

Resolution No. 201 / NQ-HDND dated December 22, 2015 of the Provincial People's Council on support for in-field traffic development in Vinh Phuc province in the period of 2017 - 2020. (2015). (Vn.).

Resolution No. 202 / NQ-HDND dated December 22, 2015 of the Provincial People's Council on specific support policies to encourage businesses to invest in agriculture and rural areas in Vinh Phuc province in the period 2016-2020. (2015). (Vn.).

Resolution No. 25/2016 / NQ-HDND dated July 21, 2016 of the Provincial People's Council on a number of mechanisms and policies to support the restructuring of the agricultural sector in Vinh Phuc province in the 2016-2020 period. (2016). (VN.).

Son, D (2006). Vietnam Agriculture and Rural Development 20 years of innovation and development. Hanoi, National Political Publishing House (Vn.).

Son, T. (2005). Linking the four houses and the role of scientist. Citizens Magazine. [Online] Available:https://nhandan.com.vn/chuyen-lam-an/lien-ket-bon-nha-va-vai-tro-cua-nha-khoa-h oc-404824

Sure, H. (2011). Hau Giang focuses on investment in agricultural development and new rural construction. Communist Magazine No. 823 (5/2011) (Vn.).

The World Bank (2018). Agribusiness and value chains. [Online] Available: https://www.worldbank.org/en/topic/agribusiness

Tien, D. (2003). Agricultural and rural comments and suggestions. Agricultural Publishing House (Vn.).

\section{Copyright Disclaimer}

Copyright for this article is retained by the author(s), with first publication rights granted to the journal.

This is an open-access article distributed under the terms and conditions of the Creative Commons Attribution license (http://creativecommons.org/licenses/by/4.0/). 